\title{
Notes on Verbena officinalis sensu stricto and V. macrostachya (Verbenaceae) with new combinations in two closely related taxa
}

\author{
P.W. Michael
}

\begin{abstract}
Michael, P.W. (National Herbarium of New South Wales, Royal Botanic Gardens, Mrs Macquaries Road, Sydney, NSW, 2000, Australia) 1997. Notes on Verbena officinalis sensu stricto and V. macrostachya (Verbenaceae) with new combinations in two closely related taxa. Telopea 7(3): 293-297. Two new combinations are made in Verbena, namely $\mathbf{V}$. gaudichaudii and V. africana which, along with $V$. macrostachya (here lectotypified) are considered to be native Australian species previously included under $V$. officinalis. Notes are given relating to the typification of $V$. officinalis sensu stricto, which is quite uncommon in Australia. Leaves of V. officinalis, V. gaudichaudii and V. africana are illustrated.
\end{abstract}

\section{Introduction}

Australian plants in MEL, BRI and NSW called Verbena officinalis L. show much variation suggesting that there are different species involved. One of these is $V$. officinalis L. sensu stricto, while there are three others which I believe, on grounds of dates of collection, distribution and morphology, to be native.

\section{Verbena officinalis L. sensu stricto}

$V$. officinalis L. sensu stricto, which occurs widely throughout Europe and Asia, appears to be quite uncommon in Australia where it is certainly introduced. It has been collected occasionally in central and eastern Victoria and rarely in New South Wales. I have collected it only once in New South Wales, along Tuena Creek between Bathurst and Crookwell in February 1997. This taxon can easily be recognized by its leaf shape (see Fig. 1) and its very glandular bracts, calyces and flowering stems. It has been well illustrated many times in Europe and Asia, for example by S. Ross-Craig (1966: t.38) and by S.J. Roles in Clapham, Tutin and Warburg (1963: Fig. 1167).

The earliest mention of its glandular inflorescence that I have been able to find is in Schauer's diagnosis of V. officinalis $\alpha$ vulgaris in Flora Brasiliensis 9: 191 (1851) which I reproduce here:

caule erecto, brachiato-ramoso; foliis ambitu oblongis trifidis tripartitisve segmentis incisis vel laciniatis laciniis crenato-serratis; rhachi bracteisque calycibusque hirtellis glandulosisque.

Of the four syntypes of $V$. officinalis noted by Verdcourt (1992: 6), he has chosen as lectotype the specimen Herb. Clifford: 11, Verbena No. 6, fol. 6 (BM) (Jarvis et al. 1993: 98). I would expect this specimen to be from Central Europe (Linnaeus wrote: 'Habitat in Europae mediterraneae ruderatis' in Sp. Pl. 1. 20-21 (1753) and 'crescit juxta areas \& vias inque locis ruderatis per Belgium, Angliam, Galliam \&c.' in Hort. Cliff.: 11 (1737)) and to have glandular inflorescences. Glandular inflorescences, although not mentioned by Linnaeus or in any of the works he cites, appear in all but one immature specimen in a large number of specimens examined by me from Europe and Asia in NSW and MEL. 
$q \psi \psi \psi \psi$ 


\section{V. officinalis L. var. gaudichaudii Briq.}

This variety was described by Briquet in 1907 (see below) as follows:

A var. genuina Briq. differt foliis caulinis elongato-lanceolatis, angustis, profunde inciso-dentatis, ad $7 \mathrm{~cm}$ longis et $8 \mathrm{~mm}$ latis, appendicibus circ. $2-5 \mathrm{~mm}$ altis, superioribus lineari-lanceolatis pauce et superficialiter dentatis, summis linearibus subintegris. Planta habitu a typo valde aliena, tamen vix segreganda.

I believe that plants like this described by Briquet occur throughout a large part of eastern Australia, that they are definitely native and that they are sufficiently distinct to raise to specific level. Many of these plants have no obvious glands in the inflorescence and quite inconspicuous vestiture. A practical reason for giving this taxon specific status is that it appears to include significant intraspecific taxa which await further elucidation.

Accordingly, I make the new combination:

Verbena gaudichaudii (Briquet) P.W. Michael, comb. et stat. nov.

Verbena officinalis L. var. gaudichaudii Briq. in Annuaire Conserv. Jard. Botan. Genève 10: 105 (1907).

Type: Australia: Port Jackson, Gaudichaud 144 (holo G, not seen)

The distinctive leaves of $V$. gaudichaudii, well described by Briquet, are illustrated in Fig. 2.

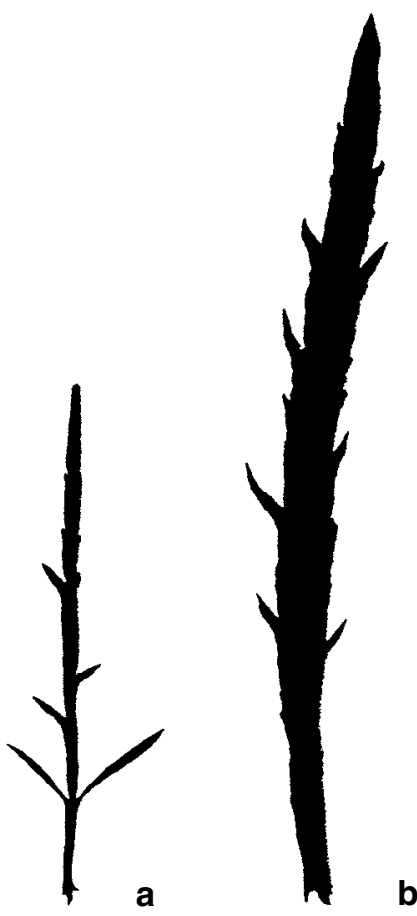

b
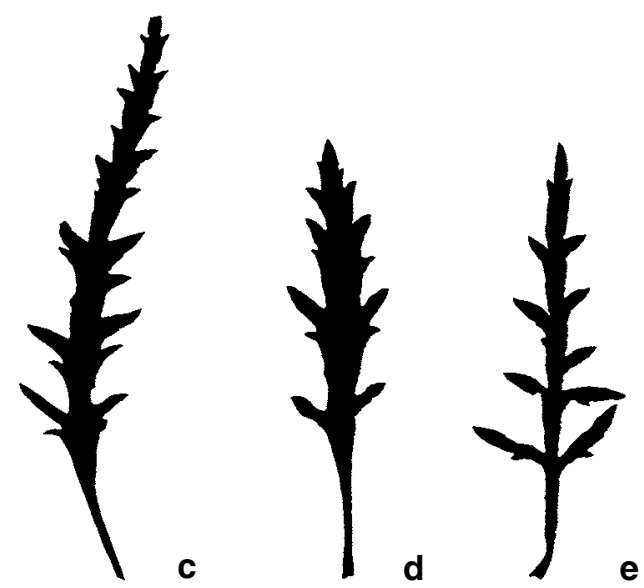

Fig. 2. Leaves of $V$. gaudichaudii, all from N.S.W. $(\times 1)$ a, from small plant collected by J. Hosking in Oxley Park, Tamworth (NSW); b, from large plant collected by J. Hosking in Oxley Park, Tamworth (NSW); c, d, from plants collected by P. Michael, near Gordon Duff Bridge, Forbes (NSW); e, from plants collected by D. King along Ellis Lane, Forbes (NSW). 

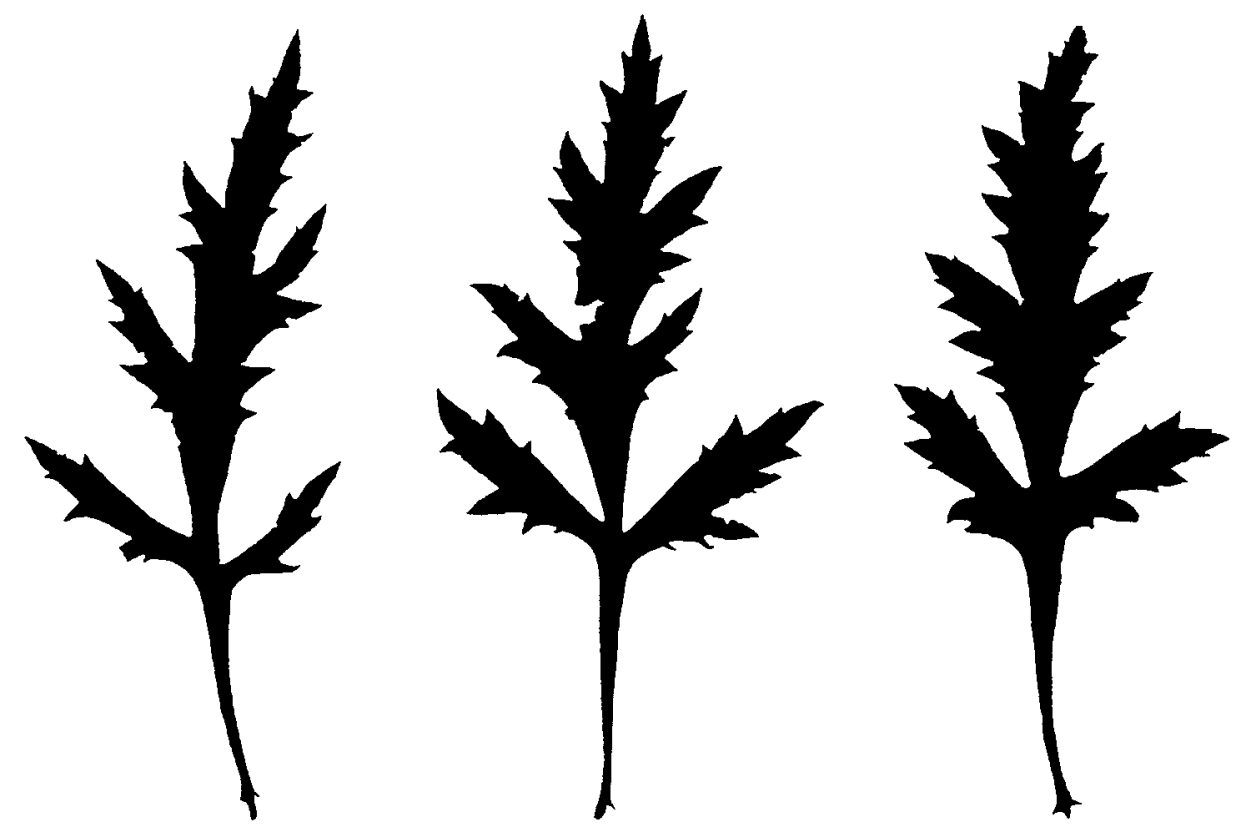

Fig. 3. Leaves of V. africana from plants collected by P. Michael at Lake Lalbert, Victoria $(\mathrm{NSW})(\times 1)$.

\section{V. officinalis L. subsp. africana R. Fernandes \& Verdc.}

This taxon with glandular inflorescence and sharply dentate leaves (see Fig. 3), of unknown extent in Australia, was recently described from Africa by Fernandes and Verdcourt (1989). It also occurs in the Indian sub-continent and, I think, is native in Australia. I collected it at Lake Lalbert in Victoria in November 1996. Occasional specimens from far western New South Wales may belong here. I consider that it is sufficiently distinct from $V$. officinalis L. sensu stricto and the other native Australian Verbena species to give it specific status also. In the original description Fernandes and Verdcourt questioned whether it might not be considered as a species in its own right. The new combination required is:

Verbena africana (R. Fernandes E Verdcourt) P.W. Michael, comb. et stat. nov.

Verbena officinalis L. subsp. africana, R Fernandes \& Verdcourt, Bol. Soc. Brot., ser. 2, 62: 305-10 and Tab. I (1989).

Type: Africa tropica: Zimbabwe: Harare (Salisbury) inter 'Avondale West and Mabelreign', alt. 1480 m, ubi, 21. viii. 1955, Drummond 4858 (holo K, not seen; iso B, BR, LISC, S, SRGH, not seen)

The plate is also reproduced in Verdcourt (1992: 7). There is an excellent drawing by A. Walters of this taxon (as V. officinalis) in Henderson \& Anderson (1966: fig. 128 p.259).

\section{Acknowledgments}

I thank Joy Everett, Karen Wilson, Peter Wilson and Max Gray for helpful suggestions, John Hosking for the collection of a specially requested range of specimens of V. gaudichaudii from Tamworth and Debby McGerty for the final preparation of the figures. 


\section{References}

Bentham, G. (1870) Flora Australiensis, vol. 5 (Reeve: London).

Brown, R. (1810) Prodromus Florae Novae Hollandiae (R. Taylor: London).

Brown, R. (1814) General Remarks - Geographical and Systematical on the Botany of Terra Australis. (London). Also in M. Flinders (1814) Voyage to Terra Australis, vol.2., Appendix III, p.592 (London).

Clapham, A.R., T.G. Tutin \& E.F. Warburg (1963). Flora of the British Isles: Illustrations III (Cambridge University Press: Cambridge).

Fernandes, R.B. \& B. Verdcourt (1989) A new African subspecies of Verbena officinalis L. Bol. Soc. Brot., ser. 2, 62: 305-10.

Henderson, M. \& J.G. Anderson (1966) Common Weeds of South Africa. Memoir 37 of the Botanical Survey of South Africa.

Henderson, R.J.F. (ed.) (1997) Queensland Plants. Names and Distribution. (Queensland Herbarium: Brisbane).

Jarvis, C.E., F.R. Barrie, D.M. Allan, \& J.L. Reveal, (1993) A list of Linnaean generic names and their types. Regnum Vegetabile, vol. 127.

Jessop, J. (ed.) (1981) Flora of Central Australia (Australian Systematic Botany Society/Reed: Sydney).

Kloot, P.M. (1984) The introduced elements of the flora of Southern Australia. J. Biogeography 11:63-78.

Mueller, F. (1858) Fragmenta Phytographiae Australiae 1: 60.

Ross-Craig, S. (1966) Drawings of British Plants. Part 23 (Bell: London).

Tate, R. (1883) Bibliographical notes refuting the alleged alien nature of two species of South Australian Plants. Trans. Proc. Rep. Royal Soc. South Australia (1882-3) 6: 174.

Verdcourt, B. (1992) Flora of Tropical East Africa-Verbenaceae. (A.A. Balkema: Rotterdam/Brookfield)

Manuscript received 5 August 1997

Manuscript accepted 10 November 1997 
